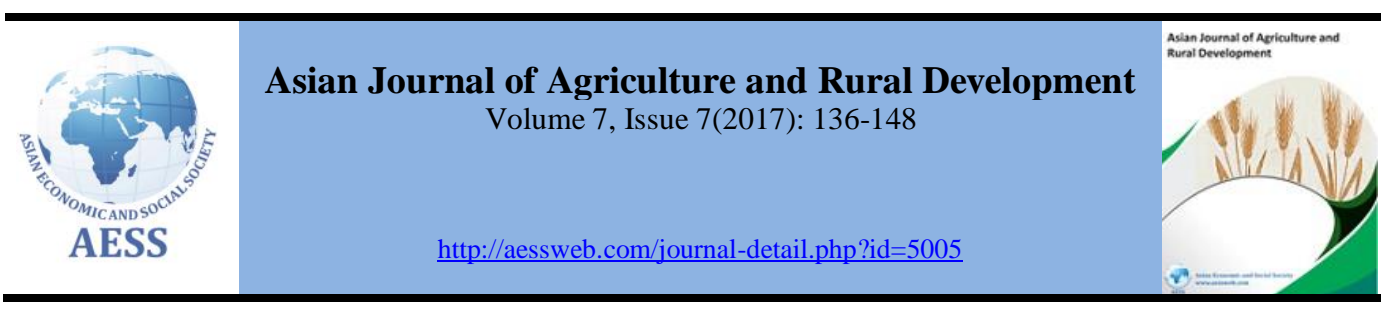

\title{
Cost and benefit analysis of adoption of climate change adaptation options among rural rice farmers in Nepal
}

\author{
Niranjan Devkota ${ }^{a^{*}}$, Ram Kumar Phuyal ${ }^{\mathrm{b}}$, Durga Lal Shrestha ${ }^{\mathrm{c}}$ \\ $\mathrm{a}^{*}$ Doctoral Candidate in Economics, Tribhuvan University, Kritipur, \\ Kathmandu, Nepal. \\ ${ }^{\mathrm{b}}$ Associate Professor, Center for Economic Development and \\ Administration, Tribhuvan University, Nepal. \\ 'Professor of Economics, Tribhuvan University, Nepal. \\ *Email address: niranjandevkota@gmail.com (Corresponding Author)
}

Corresponding Author

\section{ARTICLE HISTORY:}

Received: 05-Jan-2018

Accepted: 06-Feb-2018

Online available: $22-\mathrm{Feb}-$ 2018

\section{Keywords:}

Climate change, Adaptation options, Cost benefit analysis, Rural rice farmers, Nepal

\begin{abstract}
This paper estimates cost and benefit of adoption of climate change adaptation options available to the rural rice farmers of Nepal. Multistage sampling technique was used to source respondents for the study and used structured questionnaire techniques to collect data from 773 households from seven districts - 3 from Terai and 4 from Hilly region of Nepal. The result revealed that there are 13 major adaptation options rice farmers practice in order to protect themselves from climatic risk. Among the given adaptation options, the first three costly adaptation options are the alternative irrigation practice which incurred average cost of US \$ 69.95 (US\$ $1=102.84$ Nepalese Rupees), followed by denser plantation of local seeds (\$20.69) and using climate smart varieties (\$18.06). Nearby $88 \%$ farmers practiced more than one adaptation strategies on the same farm with the aim of reducing the effect of extreme climatic conditions. Total cost and revenue revealed that per unit total cost ranges from $\$ 28.34$ to $\$ 32.79$ whereas per unit total revenue ranges $\$ 33.4$ to $\$ 49.02$. Surprisingly, it is observed that farmers who do not adopt any adaptation options are able to received highest income from per unit production.
\end{abstract}

\section{Contribution/ Originality}

This paper contributes to the ongoing discussion on the adoption of climate change adaptation options among rural farmers from the calculation of the cost and benefit of the adoption of several climate change adaptation options in the case of Nepalese rural rice farmers.

DOI: 10.18488/journal.1005/2017.7.7/1005.7.136.148

ISSN (P): 2304-1455/ISSN (E):2224-4433

Citation: Niranjan Devkota, Ram Kumar Phuyal and Durga Lal Shrestha (2017). Cost and Benefit Analysis of Adoption of Climate Change Adaptation Options among Rural Rice Farmers in Nepal. Asian Journal of Agriculture and Rural Development, 7(7), 136-148.

(C) 2017 Asian Economic and Social Society. All rights reserved. 


\section{INTRODUCTION}

Estimation of the adaptation cost of climate change started only after 1990s (Fankhauser, 2010) though the objective of this is only to refine understanding of climate change not to access adaptation costs per se (Kavikumar et al., 2010). Then after, in many literatures, the adaptation costs are defined as the expected value of avoiding climate damage in the future but they are conditional upon some future state of socioeconomic vulnerability (Levina and Tirpak, 2006; Kavikumar et al., 2010). Cost of climate change adaptation means the cost that is required for adapting climate change i.e. the cost of planning, preparation for, facilitating and implementing adaptation measures including transitional costs whereas the adaptation benefits include the avoided damage costs or the accrued advantages following adaptation and implementation measures (Levina and Tirpak, 2006; Markandya and Watkiss, 2009; Mugula et al., 2015). IPCC (2007) mentioned that such benefit as the positive externalities from the successful adaptation.

Literature shows the cost of adaptation in many dimensions and found the total adaptation cost. Bahinipati (2011) has separated adaptation costs as first generation study - who shared a common methodology for calculating the adaptation cost, first developed by the World Bank and second generation study - adaptation cost by sectors. Five sectors-agriculture, water, human health, coastal zone and infrastructure have been identified under second generation studies. He further argued, the first generation studies estimate adaptation costs without mention adaptation cost. Agrawala and Frankhusher (2008) in their study estimate the cost of adaptation as follows; World Bank (2006) - 9 to 40 billion US \$/year; Stern (2006) - 4 to 37 billion US \$/year, Oxfam (2007) - at least 50 billion US \$/year in present scenario and UNDP (2007) - 86 to 109 billion US \$/year by 2015. Similarly, the second generation studies identified the sector wise adaptation costs as; UNFCCC (2007) - 49 to 171 billion US\$ in 2030 of which developed nation requires 22 to 104 billion US\$ and developing nation required 27 - 67 billion US\$ in 2030. Agriculture sector required 14 billion US\$ in 2030 - 7 billion in developement and 7 billion in developing countries. These estimates are considered as incomplete (Bahinipati, 2011). In Nepalese context, Prasai (2010) roughly estimates \$12 million (NRs 951 million) adaptation cost for Nepalese agriculture.

Pant (2011) divided adaptation cost of agriculture into cost of behavioral adaptation, changes in farming management practices, technological adaptation and subset of adaptation costs that encompass compliance to policy options. In other sides, World Bank (2010) and Mugula et al. (2015) mentioned the benefits of climate change adaptation in agriculture are increase in productivity, greater capacity to maintain diversified assets, less stress on social relationship and reduce dread not all of which reduce so readily into measuring equivalence. Agrawala and Frankhusher (2008) pointed that adaptation is inherently local problems, unlike mitigation which is a global problem. The benefits of mitigation are shared through international boundaries whereas the costs are not. It indicates that the adaptation is local and costs and benefits of adaptation fall largely to each private actor and local government (Mendelsohn, 2012). Therefore, adapting farmer's own farm to climate change helps the farmer because the benefits are local which local farmers can captured with adaptation.

For the successful adaptation, a process of social, institutional, and organizational learning and change should be undertaken ideally within a comprehensive and iterative framework. Assessing cost and benefit of the adaptation options is an important part of this process (UNFCCC, 2010). There are several studies which have tried to capture adaptation strategies. However, it is restricted to single adaptation strategies. Kurukulasuriya and Mendelsohn (2006) show how climate affects crop choice and Kurukulasuriya and Mendelsohn (2007) show how climate affects the choice of irrigation in Africa, Animal Husbandry in Africa by Seo and Mendelshon (2008), Crop switching as a strategy for adaptation to climate change by Kurukulasuriya and Mendelshon (2008), choice of irrigation and crop by Wang et al. (2008). But, Fankhauser (2010) remarked that the knowledge of adaptation costs and benefits at the sectoral level including agriculture was still fairy limit. 
More recent studies are found on climate change adaptation (esp. private) on economics focusing agriculture. Several studies including Enete et al. (2011), Mohammed et al. (2013), Shongwe et al. (2014), Mugula et al. (2015) analyze cost and benefit of major strategies practice by the crop farmers to cope with climate change. Still a little literature is available on the cost and benefit of adoption of climate change adaptation options in South Asian Region including Nepal. Pant (2011) mentioned it is not clear what cost the farmers face and benefit received as the impact of the climate change among the rural rice farmers. It left knowledge gap in the assessment of the cost and benefits of adaptation to climate change adaptation options for rice production in Nepal. Therefore, this study aims to contribute in addressing this research gap. Understanding the costs and benefits of climate change adaptation in agriculture is important for mobilizing support and providing timely resource from institution to improve resilience and adaptive capacity (Sova et al., 2012; Mugula et al., 2015).

\section{METHOD OF THE STUDY}

\subsection{Theoretical framework}

Farmers aim to maximize net revenue (or profit) from farm production subject to exogenous factors and conditions (Mendelsohn et al., 1994; Wang et al., 2008). Net crop revenue is defined as total revenue less the total cost of production divided by the amount of land cultivated. Total costs include both fixed and variable costs such as fertilizer, seed, irrigation, labor, pesticides and machinery costs. Net revenue is a measure of returns per unit of land for each farm household. The use of net revenue is justified on the basis that it is consistent with crop yield that indicates crop productivity or farm profitability.

In an economy where crop agriculture is the major livelihood activity, the direct impact of climate change and extreme climate events are manifested in the form of a decline in crop production through a reduction in cultivated area and/or crop yield (Paul, 1998; IPCC, 2007; Challinor and Wheeler, 2008; Hisali et al., 2011). This, ultimately, reduces a farm's net revenue. A significant percentage of production loss is directly caused by climate change and extreme events such as droughts, floods and cyclones. IPCC (2007) predicted a 30\% crop yield loss in South Asia by 2050 due to climate change. According to the proponents of the structural-political economy approach of vulnerability theory, production losses of farming communities due to climate related extreme events will vary depending on their socio-demographic and farm characteristics and institutional factors (Watts, 1983; Ernel and Peet, 1989; Dreze and Sen, 1989).

In this regard, adaptation can be taken in order to minimize the harm or maximize the gains from weather variability and climate change. In the same vein, efficient adaptations are the set of adaptations that maximize net benefits (Mendelsohn, 2000). But, every adaptation is not advantageous for farmers to adapt, only the selected adaptations whose benefits exceed costs are advantageous and worthwhile (Pant, 2011). Such adaptations which maximize benefits should be encouraged. Besides, how much change is advantageous is depends upon where adaptation done. To know this, an economic analysis is necessary to determine whether or not it is advantageous doing any adaptation at all. This, further, can also be used to prioritize or choose most appropriate adaptation options.

To measure cost benefit analysis focuses on the quantitative evaluation of climate change impacts on crops and allows for estimation of the net benefits of different adaptation options and is used to assess adaptation options when efficiency is the only decision making criteria (Shongwe et al., 2013). This involves calculating and comparing all the costs and benefits expressed in monetary terms (Bruin et al., 2014). This approach identifies the most economic adaptation strategy and allows ranking all the proposed strategies based on economic efficiency. 


\subsection{The benchmark models}

The cost benefit analysis focuses on the quantitative evaluation of climate change impacts on crops and allows for estimation of the net benefits of different adaptation options and is used to assess adaptation options when efficiency is the only decision making criteria (UNFCCC, 2010; Shongwe et al., 2013). This involves calculating and comparing all the costs and benefits expressed in monetary terms (Bruin et al., 2014). This approach identifies the most economic adaptation strategy and allows ranking all the proposed strategies based on economic efficiency as Shongwe et al. (2014) mentioned in their work. Net present value (NPV) are prefer because they discount the future benefits to present values, whilst internal rate of returns (IRR) are used to evaluate the most economic adaptation strategy.

This study will conduct cost benefit analysis of adaptation options to climate change. It involves calculation and comparisons of all costs and benefits that has been expressed in monetary terms; helps to inform decision making about the efficiency of different adaptation investment and hence provide the basis for prioritizing possible cost efficient adaptation measures (UNFCCC, 2010). Following Shongwe et al. (2014), this can be done by;

i. Identifying the adaptation strategies employed in the communities.

ii. For each adaptation strategy, the total costs incurred when using the strategy and benefits were identified and to capture the net benefit for the particular adaptation strategy.

$$
\mathrm{NB}=\sum \mathrm{TB}-\sum \mathrm{TC}
$$

Where,

NB represents the net benefits

TB represents the total benefits

TC represents the total costs

For adaptations that do not have direct costs and benefits, the shadow pricing and opportunity costs have been used to quantify computed.

The NPV are computed as:

Where;

$$
\mathrm{NPV}=\sum_{\mathrm{t}=0}^{\mathrm{n}} \frac{\mathrm{B}_{\mathrm{t}}-\mathrm{C}_{\mathrm{t}}}{(1+\mathrm{i})^{\mathrm{t}}}
$$

$\mathrm{NPV}=$ net present value in year $\mathrm{t}$

$\mathrm{B}=$ total benefits in year $\mathrm{t}$

$\mathrm{C}=$ total costs in year $\mathrm{t}$

$\mathrm{i}=$ discount rate

$(1+\mathrm{i})^{\mathrm{t}}=$ discount factor for year $\mathrm{t}$

$\mathrm{t}=$ time horizon.

The adaptation strategy with the positive and highest NPV is the most economic and efficient. The NPV has been computed based on per hectare average return. BCR is computed to understand the profit status of the adoption of adaptation options. This study conducted cost benefit analysis of adaptation decision of rice farmers to cope with changing climate.

\subsection{Study area and data}

This study was done in 7 districts that ranges from Hill to Terai Belt of Nepal. This study excludes Mountain belt since rice cultivation practice on mountain belt is very rare and typically different that the study area. In this study 3 study districts come from Terai Belt and 4 comes from Hilly Belt. The reason behind choosing 7 districts is one district from each state. The study district Ilam (Hill) is located in eastern part of the country; whereas Sinhdhuli (Hill) and Bara (Terai) is located in central part of the country. Similarly, Syangja (Hill) is located in western part and Dang (Terai) and Surkhet 
(Hill) is located in the far western part of the country. Lastly, Kailali (Terai) is located in the farwestern part of the country.

To investigate the farm-level adaptation practice by rice farmers throughout the country, the selection of study districts were made based on rice pocket area from different agro ecological zones regardless of cropping patterns, irrigation networks and climate prone zone Abid et al. (2015). To select the study sites and sample farm households in the study area, a multi-stage sampling technique was used. In the first stage, the seven districts of Nepal, one each from the state, were randomly selected as the overall study area. Telephone inquiry was made to each district agriculture office in order to collect the rice pocket area, most rice cultivate area, within the district. In the second stage, 14 VDCs, two from each district, were selected on rice pocket area. Further telephone inquiry was made to each VDC secretary and social mobilizer in order cross-check the given information from district agriculture office. In the third stage, 28 rice pocket wards, two wards from each VDC, based on the information provided by VDC secretary and Social Mobilizer, were selected. In the fourth stage, 28 farmers were selected from each ward as per the convenience ${ }^{1}$ basis. During our field visit, we found the information provided was correct and the selected VDCs are the best rice pocket $\mathrm{VDCs}^{2}$ of the district. We excluded the urban cities and VDCs with the assumption that the cities and urban VDCs may have influence with market based adaptation. Selecting VDCs therefore have an advantage of less influence by such market driven adoption which is the primary reason to select VDC as a study area. Table 1 shows the study district and the selected households.

The survey was conducted between January and February in 2017. For the data collection, total 773 farmers were interviewed irrespective of gender, farm size or tenancy status through a farm household survey. Interviews were conducted for the crop year 2016 since main season rice cultivation in Nepal falls on June/July to October/November of each year. A fully structured questionnaire was used to gather information on socioeconomic characteristics, crop and domestic livestock management, land tenure, detail of farm inputs and outputs, access to various institutional services, current and past knowledge of climate change, current adaptation measures undertaken and limitations to adaptation. Prior to the study, a pretesting of the questionnaire was performed to avoid missing any important information. The enumerators received field training about the study objectives and farm household survey.

\section{RESULT AND DISCUSSION}

\subsection{Adoption of adaptation strategies}

Farmers at the present situations adopts various adaptation options to cope with the changing climate they are perceived (Mohammed et al., 2013; Shongwe et al., 2014). Adaptation plays a key role in determining the economic and social cost of climate change as its cost estimation is vital to gear up the climate talk and other activities (Sarkar et al., 2012). Several adaptation options are applied by the farmers in the study area. The common adaptation practice and the average adaptation costs bared by the farmers in order to adopt the adaptation options available to them are discussed in Table 1. The most common adaptation practice made by the rice farmers in Nepal are increase use of chemical fertilizer (60.93\%), use of climate smart verities (49.29\%) and change in nursery date $(32.08 \%)$. Similarly, the most costly adaptation options are change in irrigation practice (NRs 7914.35), denser plantation of local seeds (NRs 2128.36) and using climate smart varieties (NRs 1857.15). It indicates that farmers are using cheapest measures as far as possible.

\footnotetext{
${ }^{1}$ This study found difficulties to get the selected farmers in the first day since most of the farmers are not available in their house during the enumerators present at the area which turn the selection procedure as per the sampling with the availability of the farmers in their home at the time of data collection. However, caution was taken for the distance of household for each questionnaire. After every HH questionnaire filled, few surrounding houses are left for the sake of coverage entire study area.

${ }^{2}$ In each selected ward, rice farm households contain more than $90 \%$ of the respondents.
} 
Table 1: Common adaptation practice made by the rice farmers $(n=773)$

\begin{tabular}{|c|c|c|c|c|c|c|}
\hline $\begin{array}{l}\text { Adaptation Strategy } \\
\text { Practiced }\end{array}$ & Frequency & Percentage & $\begin{array}{c}\text { Average } \\
\text { Cost }\end{array}$ & $\begin{array}{l}\text { Number of } \\
\text { Respondent }\end{array}$ & NPV & BCR \\
\hline $\begin{array}{l}\text { Change in rice } \\
\text { varieties }\end{array}$ & 381 & 49.29 & - & - & 976.82 & 1.3 \\
\hline $\begin{array}{l}\text { Denser Plantation of } \\
\text { Local seeds }\end{array}$ & 102 & 13.20 & 1857.15 & 133 & 1112.38 & 1.35 \\
\hline $\begin{array}{l}\text { Selecting short } \\
\text { duration crop varieties }\end{array}$ & 232 & 30.01 & 2128.36 & 52 & 1218.6 & 1.37 \\
\hline Rice Crop Switching & 53 & 6.86 & - & - & 1345.06 & 1.48 \\
\hline $\begin{array}{l}\text { Increasing use of } \\
\text { chemical fertilizer, } \\
\text { pesticides, insecticides }\end{array}$ & 471 & 60.93 & 1643.04 & 48 & 898.46 & 1.29 \\
\hline $\begin{array}{l}\text { Starting/Increasing use } \\
\text { of Vitamins }\end{array}$ & 123 & 15.91 & 1840.43 & 195 & 1020.28 & 1.41 \\
\hline $\begin{array}{l}\text { Changing size of land } \\
\text { under cultivation }\end{array}$ & 33 & 4.27 & - & - & 1208.66 & 1.52 \\
\hline Off farm activities & 26 & 3.36 & - & - & 1491.72 & 1.56 \\
\hline $\begin{array}{l}\text { Change in Nursery } \\
\text { date }\end{array}$ & 248 & 32.08 & 1053.02 & 43 & 1087.46 & 1.33 \\
\hline Changing planting date & 220 & 28.46 & NA & - & 994.25 & 1.3 \\
\hline $\begin{array}{l}\text { Build Water harvesting } \\
\text { system }\end{array}$ & 4 & 0.52 & NA & - & 489.33 & 1.2 \\
\hline $\begin{array}{l}\text { Change in Irrigation } \\
\text { Practice }\end{array}$ & 171 & 22.12 & 7914.35 & 117 & 418.75 & 1.14 \\
\hline
\end{tabular}

Source: Researcher's calculation from survey data, 2017

Every adaptation strategies were observed as per its cost for the production of rice production. Farmers are always intended to know the best adaptation strategies among the available strategies in order to have better profit. It is observed that per unit net profit is higher with the strategies such as off-farm activities, rice-crop switching, selection of short duration rice verities and change size of land under cultivation. Average per unit NPV is observed with the most commonly practiced adaptation options such as change in rice verities, increase in use of chemical fertilizer and change in nursery and planting date. It is also observed that irrigation with alternative sources gives very less net profit to the farmers. BCR for entire adaptation options is positive indicates that using adaptation options is helping farmers to grow more production and, hence, profit.

\subsection{Intensity of Use of adaptation strategies}

Intensity of use of adaptation strategies was measured by the number of adaptation strategy (ies) practiced by respondents on their rice field. Farmers are not restricted with single adaptation options rather they practice multiple adaptation strategies as it revealed that $88 \%$ of the rice farmers practice more than one adaptation strategies on the same farm with the aim of reducing the effect of extreme climate condition. Similarly, $21.17 \%$ practiced five strategies, $16.90 \%$ practice four strategies, $16.37 \%$ practiced two adaptation strategies and $11.9 \%$ practice only one adaptation strategy. A dismal $0.53 \%$ and $0.18 \%$ of the respondents practiced seven and eight adaptation strategies respectively. This result corroborated the previous findings of Mohammed et al. (2013) who observed that farmers practiced adaptation strategies in complementary way rather than taking them as an independent strategy.

Cost and returns are another important component to know how many adaptation strategies is more suitable famers as per the benefit they received from such practices. Total land holding is very less with the farmers who do not adopt any adaptation strategies which indicate that small size land 
holding farmers are the one who adopt less compare to large size land holding. It is also observed that both NPV and BCR of using no adaptation options strategies are higher among other intensity of adaptation options. Similarly, for every adaptation options used by the farmers NPV is positive and BCR is greater than 1 that indicates farmers are able to earn profit for all the adaptation options they use for their land to protect climate anomalies. It means, the available adaptation options are profitable to the rice farmers. The table 2 shows the cost and returns of adaptation strategies based in their intensity of practice.

Table 2: Net present value and benefit cost ration of intensity of practice

\begin{tabular}{lcccc}
\hline $\begin{array}{l}\text { Intensity of } \\
\text { Adaptation Practice }\end{array}$ & No. of Farmers & $\begin{array}{c}\text { Average Land } \\
\text { Holding }\end{array}$ & NPV & BCR \\
\hline 0 & 215 & 11.76 & 1777.04 & 1.54 \\
1 & 67 & 19.64 & 955.27 & 1.29 \\
2 & 92 & 27.1 & 1232.37 & 1.39 \\
3 & 127 & 21.41 & 892.24 & 1.29 \\
4 & 95 & 21.31 & 713.03 & 1.23 \\
5 & 119 & 16.57 & 1247.53 & 1.37 \\
6 & 58 & 19.72 & 520.18 & 1.18 \\
\hline
\end{tabular}

Source: Researcher's calculation from survey data, 2017

Table above shows that farmers who do not adopt have highest average net profit of NRs. 1777 . With the farmers who adopt several adaptation options, the farmers who practice five adaptation strategies have highest average net profit of NRs 1247.43 per Kattha followed by the farmers who practice two adaptation strategies i.e. NRs 1232.37 per Kattha. Respondents who practices one, three, four and six adaptation strategies had net profit of NRs 955.27; NRs 892.24; NRs 713.03 and NRs 520.18 per Kattha respectively. Here too, BCR is more than 1 for every adaptation practice pattern, it indicates farmers will be in profit for any types of adaptation but higher with no adaptation at all. It is also found that most of the respondent who has adopted adaptation options practices multiple adaptation rather than only a single adaptation options and net profit is also shows higher to such multiple adaptation practice rice farmers. Farmers mentioned that the major causes of adoption of available adaptation options are climate change (59\%), easy access to market (13\%) and improvement in technology (6\%). Such adaptation options are helpful to them to cope from the changing climate.

\subsection{Cost benefit analysis of climate change adaptation by rice farmers}

Our study divide labor input into three phases - land preparation and seed showing, wedding and dressing and harvesting and grain separation. Therefore, land preparation and seed showing costs basically cover the labor costs for first plowing, pudding, manure, nursery bed preparation and rice transplant. Similarly, wedding and dressing costs include labor costs for wedding and top dressing. Likewise expenses such as labor costs for harvesting including transportation; threshing and drying are calculated under harvesting and grain separation. Like labor input, non-labor input is equally important sources of input in order to cultivate better rice production. That indicates various nonlabors input such as seeds, organic fertilizer, manure, pesticides and herbesticides and chemical fertilizer - mainly Urea, Potash and Phosphorous are also equally required for rice production. On the revenue part, the output is rice grain and straw as a by-product. The overall revenue received from both production and by product is calculated.

We measure per unit (i.e. Per Kattha) cost and revenue from of total respondent, responded from Terai and Hill separately. Similarly, all these respondents are further subdivided into adopter and non-adopter as per the basis of adaptation options adopted for the rice production process or not. Table 3 shows the cost and revenue status of all the mentioned rice farmers. The overall land use by the farmers are 18.93 Kattha which is classified by 20.76 Kattha use by farmers who has been 
adopted different adaptation strategies and 12.09 Kattha from those farmers who have not adopted any strategies yet. It indicates that rice farmers' who adopt poses more land compared to non-adopter rice farmers. Similarly, farmers' from Terai region holds average land of 29.23 Kattha, approx. three times more, for rice production compared to 10.10 Kattha from the Hilly farmers.

Per unit cost of land preparation and showing shows the first land preparation to plantation stage. The cost includes labor, bullock and tractor cost as per farmers applied for their land. This study finds the overall land preparation and showing cost is NRs 1213.89 whereas such cost is NRs 1219.01 for farmers who adopt various adaptation strategies and NRs 1200.24 for non-adopter farmers. It indicates farmers who adopt various adaptation options require more cost for land preparation and showing compared to the farmers who cultivate traditional rice crops with similar pattern. Such high price for farmers who adopt is found in the case of all the rice farming region which shows every region follows similar pattern in terms of land preparation and showing that increase costs to the farmers. 
Table 3: Per unit cost and benefit analysis of climate change adaptation

\begin{tabular}{|c|c|c|c|c|c|c|c|c|c|}
\hline \multirow[b]{2}{*}{ Heading } & \multicolumn{3}{|c|}{$\begin{array}{c}\text { Cost Benefit Analysis of Total } \\
\text { Respondent }\end{array}$} & \multicolumn{3}{|c|}{$\begin{array}{c}\text { Cost Benefit Analysis of Terai } \\
\text { Region }\end{array}$} & \multicolumn{3}{|c|}{$\begin{array}{c}\text { Cost Benefit Analysis of Hilly } \\
\text { Region }\end{array}$} \\
\hline & $\begin{array}{c}\text { Total } \\
(\mathrm{n}=773)\end{array}$ & $\begin{array}{c}\text { Adapter } \\
(\mathbf{n}=562)\end{array}$ & $\begin{array}{c}\text { Non } \\
\text { Adapter } \\
(\mathbf{n}=\mathbf{2 1 1}) \\
\end{array}$ & $\begin{array}{c}\text { Total } \\
(\mathbf{n}=\mathbf{3 3 5})\end{array}$ & $\begin{array}{c}\text { Adopter } \\
(\mathrm{n}=317)\end{array}$ & $\begin{array}{c}\text { Non } \\
\text { Adopter } \\
(\mathbf{n}=18)\end{array}$ & $\begin{array}{c}\text { Total } \\
(n=438)\end{array}$ & $\begin{array}{c}\text { Adopter } \\
(\mathrm{n}=\mathbf{2 4 5})\end{array}$ & $\begin{array}{c}\text { Non } \\
\text { Adopter } \\
(\mathrm{n}=193)\end{array}$ \\
\hline Total Land & 18.39 & 20.76 & 12.09 & 29.23 & 29.18 & 30.17 & 10.10 & 9.87 & 10.40 \\
\hline Per Unit Cost of Land Preparation & 1213.89 & 1219.01 & 1200.24 & 1017.26 & 1025.90 & 865.12 & 1364.27 & 1468.87 & 1231.49 \\
\hline Per Unit Weeding and Dressing & 451.58 & 456.18 & 439.32 & 381.88 & 393.43 & 178.48 & 504.89 & 537.37 & 463.64 \\
\hline Per Unit Harvesting and Grain Seperation & 767.23 & 754.64 & 800.76 & 561.44 & 572.36 & 369.15 & 924.62 & 990.49 & 841.01 \\
\hline Per Unit Non-Labor Cost & 756.14 & 762.73 & 738.56 & 734.55 & 745.86 & 535.39 & 772.65 & 784.57 & 757.51 \\
\hline Per Unit Production Income & 3601.21 & 3492.95 & 3889.59 & 2911.58 & 2929.26 & 2600.15 & 4128.67 & 4222.28 & 4009.85 \\
\hline Per Unit Income of By Product & 786.01 & 691.88 & 1036.74 & 354.18 & 355.91 & 323.64 & 1116.30 & 1126.57 & 1103.25 \\
\hline Total Per Unit Cost (i.e. Per Kattha) & 3188.84 & 3192.56 & 3178.88 & 2695.13 & 2737.55 & 1948.14 & 3566.43 & 3781.3 & 3293.65 \\
\hline Total Per Unit Revenue (i.e. Per Kattha) & 4387.22 & 4184.83 & 4926.33 & 3265.76 & 3285.17 & 2923.79 & 5244.97 & 5348.85 & 5113.1 \\
\hline NPV & 1198.40 & 992.26 & 1747.45 & 570.63 & 1678.54 & 547.64 & 975.64 & 1567.55 & 1819.43 \\
\hline $\mathrm{BCR}$ & 1.38 & 1.31 & 1.55 & 1.21 & 1.47 & 1.20 & 1.50 & 1.41 & 1.55 \\
\hline
\end{tabular}

Source: Researcher's calculation from survey data, 2017 
Weeding and Dressing also shows more cost per unit is required for the farmers who adopt several adaptation options compared to non-adopter farmers. Our calculation shows overall farmers from entire region requires labor cost of NRs 451.58 for weeding and dressing while farmers from Terai region and Hilly region requires NRs 381.88 and NRs 504.89 per Kattha respectively. Cost of weeding in Hilly region is more than Terai region because rice farmers at Terai region mostly use chemical fertilizer and pesticides instead of weeding.

Harvesting and Grain separation is another component that requires human labor and achine. The average harvesting and grain separation cost is NRs 767.23 per Kattha. Such harvesting cost is lower in Terai region i.e. NRs 561.44 to the Hilly region i.e. NRs 924.00 per Kattha. This difference can be attributed to the mechanization. Farmers from Terai region mainly use Tractor and Threshers to separate grain that comparatively takes lower time than the manual work made by the Hilly farmers. Hand operating Threshers are available in some area of Hilly region but such Thresher required large number of manpower. Similarly, the overall cost of harvesting and grain separation is lower to the farmers who adopt in both regions. Farmers during survey revealed that rice straw is short for HYV varieties that reduce both harvesting time and cost of grain separation. But in separate data, cost of harvesting and grain separation for farmers who adopts are more for both regions, it may be the impact of heterogeneity in number of respondent lies in the both category.

The overall non-labor cost which is the comprises of seeds, manure, pesticides and fertilizer that consists Urea, Potash and DAP, are NRs 756.14 per Kattha which is measured NRs 762.73 per Kattha for farmers who adopt various adaptation measures and NRs 738.56 per Kattha for those farmers who have not adopted yet. Such cost is found more for Hilly farmers than the farmers belong to Terai region. It is because Terai region has very easy facility of seeds and fertilizer along with cheapest labor for per day work compared to Hilly area. It is also revealed that the overall non-labor cost is high for the farmers who adopt in comparison to the farmers who does not adopt in both region.

Though there are many costs for rice production, its revenue can be generating only from two things that is product (rice grains) and by-product (straw). It is calculated that the overall income from per Kattha rice yield is NRs 3601.21 where income of the farmers who adopt adaptation options are NRs 3492.95 per Kattha compared to NRs 3889.59 per Kattha of non-adopter farmers. It is seems surprising result that non-adopter rice farmers are in more benefit from the production results compared to the adopter rice farmers. Farmers, during survey mentioned that they are not ending rice of HYV seeds and sell it in lower price. Also, they mentioned that such product is highly pest attractive and not suitable to store for longer period whereas the traditional seed has quality of rice and last longer and cost high. This is also responsible to increase in income level of non-adopter farmers. Similar to income, overall by-product income is high to the farmers who do not adaptation options compared to those farmers who adopt. During interview farmers argued that small and shorter straw which results low income from by-product of adopted seeds.

The overall cost per Kattha is measured NRs 3188.84 which is more with farmers who adopted several adaptation options i.e. NRs 3192 in comparison to the farmers who does not adopt i.e. NRs 3178 per Kattha. Such cost is lower in Terai region compared to hilly region for both adopted and non-adopted farmers. It shows farmers who adopt bears more cost as per their counterparts in both regions. Similar to cost, the overall per unit benefit is 4382.22 per Kattha where non-adopters rice farmers are able to have (received) high revenue from farmers who adapt adaptation options. But in separate data of Terai and Hill revenue received by rice farmers who adopt is more than the farmers who does not adopt. Net profit of farmers who does not adopt any adaptation options are high compared to non-adopters rice farmers. The overall profit ratio is double for entire survey but such ratio is narrower with the farmers in hilly region. However, it can be conclude that non-adapter farmers have leads more profit to adaptation as it reduce input cost. 
Farmers were also asked for the opportunity cost of their land. $71 \%$ farmers opined that they have no alternatives of the rice farming and $29 \%$ of the farmers mentioned that they can adopt several alternative crops. Farmers argued cereal crops - maize; cash crops like lentils, sugarcane, mustard, asparagus and fruits like banana, medicinal herbs and so on. Similarly, most of the land if farmers will provide it to the lease will receive half of the product.

\section{CONCLUDING REMARKS}

Even though farmers practice adaptation options and intensity of such adaptation is more than one strategy on the same farm, farmers are using cheapest measures as far as possible. Total cost and revenue calculation revealed that per unit total cost ranges from NRs 2914.95 to NRs 3372.17 whereas per unit total revenue ranges NRs 3435.13 to NRs 5041.76. Surprisingly, it is observed that farmers who do not adopt any adaptation options are able to received highest income from per unit production. One reason could be the no cost for adaptation options. For the farmers who used adaptation options shows that the value of NPV and BCR is greater than 1 for every adaptation options used indicates farmers are able to earn profit for all the adaptation options they use for their land to protect climate anomalies. Farmers mentioned that the major causes of adoption of available adaptation options are climate change (59\%), easy access to market (13\%) and improvement in technology $(6 \%)$. Such adaptation options are helpful to them to cope from the changing climate. Our study also revealed farmers' adaptation strategies differs with the adaptation options and the knowledge they perceived regarding such adaptation options. Therefore, government policy should target improving this significant determinants to boost farmers adaptation and hence to reduce vulnerability. Focusing on cost of adaptation options is advantage.

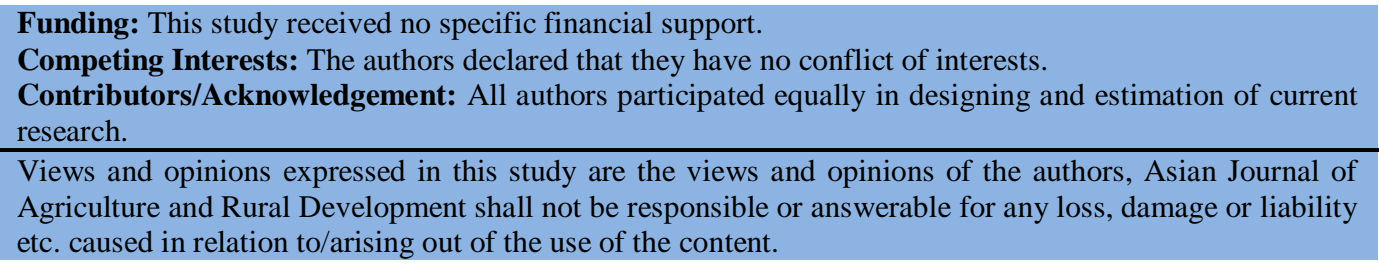

\section{Reference}

Abid, M., Scheffran, J., Schneider, U. A., \& Ashfaq, M. (2015). Farmers' perceptions of and adaptation strategies to climate change and their determinants: the case of Punjab province, Pakistan. Earth System Dynamics, 6(1), 225-243. view at Google scholar / view at publisher

Agrawala, S., \& Fankhauser, S. (2008). Economic aspects of adaptation to climate change. Costs, Benefits and Policy Instruments. Paris: OECD. view at Google scholar / view at publisher

Bahinipati, C. S. (2011). Economics of adaptation to climate change: learning from impact and vulnerability literature. Working Paper no. 213, Madras Institute of Development Studies, Chennai. view at Google scholar / view at publisher

Bruin, K., Goosen, H., van Ierland, E. C., \& Groeneveld, R. A. (2014). Costs and benefits of adapting spatial planning to climate change: lessons learned from a large-scale urban development project in the Netherlands. Regional Environmental Change, 14(3), 1009-1020. view at Google scholar / view at publisher

Challinor, A. J., \& Wheeler, T. R. (2008). Crop yield reduction in the tropics under climate change: processes and uncertainties. Agricultural and Forest Meteorology, 148(3), 343-356. view at Google scholar / view at publisher

Dreze, J., \& Sen, A. K. (1989). Hunger and public action. Clarendon, Oxford: Clarendon Press. view at Google scholar / view at publisher

Enete, A. A., Madu, I. I., Mojekwu, J. C., Onyekuru A. N., Onubuya E. A., \& Eze, F. (2011). Indigeneous agricultural adaptation to climate change: Study of Imo and Enugu states in 
southeast Nigeria. Working Paper Series 53, African Technology Policy Studies Network. view at Google scholar

Ernel, J., \& Richard, P. (1989). Resource management and natural hazards. In. New models in geography: The political-economy perspective (Vol. 1). Peet, R. \& Thrift, N. (Eds.). Routledge, London: Taylor \& Francis Group. view at Google scholar / view at publisher

Fankhauser, S. (2010). The costs of adaptation. Wiley interdisciplinary reviews: climate change, 1(1), 23-30. view at Google scholar / view at publisher

Hisali, E., Birungi, P., \& Buyinza, F. (2011). Adaptation to climate change in Uganda: evidence from micro level data. Global Environmental Change, 21(4), 1245-1261. view at Google scholar / view at publisher

IPCC (2007). Impacts, adaptation and vulnerability. Contribution of working group II to the fourth assessment report of the intergovernmental panel on climate change, Cambridge university press, Cambridge, UK. view at Google scholar

Kavikumar, K. S., Shyamsundar, P., \& Nambi, A. A. (2010). The economics of climate change adaptation in India-Research and policy challenges ahead. SANDEE policy note, 42-10. view at Google scholar

Kurukulasuriya, P., \& Mendelsohn, R. O. (2007). Modeling endogenous irrigation: The impact of climate change on farmers in Africa (World Bank Policy Research Working Paper 4278). Washington D.C.: The World Bank. view at Google scholar

Kurukulasuriya, P., \& Mendelsohn, R. (2006). Crop selection: adapting climate change in Africa. (Policy Research Working Paper No. 4307). Washington D.C.: The World bank. view at Google scholar / view at publisher

Kurukulasuriya, P., \& Mendelsohn, R. (2008). A Ricardian analysis of the impact of climate change on African cropland. African Journal of Agricultural and Resource Economics, 2(1), 1-23. view at Google scholar / view at publisher

Levina, E., \& Tirpak, D. (2006). Adaptation to climate change. Key Terms. France: International Energy Agency, Organisation for Economic Co-operation and Development (OECD). Available at http://www.oecd.org/environment/cc/36736773.pdf.

Markandya, A., \& Watkiss, P. (2009). Potential Costs and Benefi ts of Adaptation Options: A review of existing literature. UNFCCC Technical Paper. F CDCeCce/mTPb/e2rO, 20090, 29. view at Google scholar

Mendelsohn, R. (2000). Efficient adaptation to climate change. Climatic Change, 45(3), 583-600. view at Google scholar

Mendelsohn, R. (2012). The economics of adaptation to climate change in developing countries. Climate Change Economics, 3(2), 1250006. view at Google scholar / view at publisher

Mendelsohn, R., Nordhaus W., \& Shaw, D. (1994). The impacts of global warming on agriculture: a ricardian analysis. American Economic Review, 84, 753-771. view at Google scholar I view at publisher

Mohammed, D., Kwaghe, P. V., Bukar, U., \& Umar, J. (2013). Economics of adaptation to climate change among farmers in Adamawa state, Nigeria. IOSR Journal of Agriculture and Veterinary Science, 5(4), 61-66. view at Google scholar / view at publisher

Mugula, V. J., Kadigi, I. L., Mutabazi, K. D., \& Tumbo, S. D. (2015). Economics of climate change adaptation in smallholder rice production in Wami-river basin, Tanzania. Researchjournali's Journal of Agriculture, 2(5), 1-16.

Oxfam (2007). Adapting to Climate Change. What is needed in Poor Countries and Who Should Pay? (Oxfam Briefing Paper No. 104). UK: Oxfam International. view at Google scholar

Pant, K. P. (2011). Economics of climate change for smallholder farmers in Nepal: a review. Journal of Agriculture and Environment, 12, 113-126. view at Google scholar / view at publisher

Paul, B. K. (1998). Coping mechanisms practised by drought victims (1994/5) in North Bengal, Bangladesh. Applied Geography, 18(4), 355-373. view at Google scholar / view at publisher

Prasai, B. K. (2010). National issue paper on agriculture sector (adaptation). United Nations Development

(UNDP).

Available at 
http://www.undpcc.org/docs/National\%20issues\%20papers/Agriculture\%20(adaptation)/1 7 Nepal\%20NIP \%20agriculture\%20adaptation.pdf.

Sarkar, A., Aronson, K. J., Patil, S., \& Hugar, L. B. (2012). Emerging health risks associated with modern agriculture practices: A comprehensive study in India. Environmental research, 115, 37-50. view at Google scholar / view at publisher

Seo, S. N., \& Mendelsohn, R. (2008). An analysis of crop choice: Adapting to climate change in South American farms. Ecological economics, 67(1), 109-116. view at Google scholar $/$ view at publisher

Shongwe, P., Masuku, M. B., \& Manyatsi, A. M. (2013). Cost benefit of climate change adaptation strategies on crop production systems: A case of Mpolonjeni area development programme (ADP) is Swaziland. Sustainable Agriculture Research, 3(1), 37-49. view at Google scholar

Shongwe, P., Masuku, M. B., \& Manyatsi, A. M. (2014). Factors influencing the choice of climate change adaptation strategies by households: a case of Mpolonjeni Area Development Programme (ADP) in Swaziland. Journal of Agricultural Studies, 2(1), 86-98. view at Google scholar / view at publisher

Sova, C., Chaudhury, A., Helfgott, A., \& Corner-Dolloff, C. (2012). Community-based adaptation costing: an integrated framework for the participatory costing of community-based adaptations to climate change in agriculture. CGIAR Working Paper No. 16. CGIAR Research Program on Climate Change, Agriculture and Food Security (CCAFS). Available at www.ccafs.cgiar.org.

Stern, N. H. (2006). The economics of climate change: The Stern review. Cambridge, UK: Cambridge University Press. view at Google scholar

UNDP (2007). Human development report 2007/08. New York: Palgrave McMillan.

UNFCCC (2010). Assessing the costs and benefits of adaptation options: an overview of approaches. The Nairobi Work Programme on Impacts, Vulnerability and Adaptation to Climate Change. Available at http://unfccc.int/resource/docs/publications/pub_nwp_costs benefits adaptation.pdf.

Wang, J., Mendelsohn, R. O., Dinar, A., \& Huang, J. (2008). How China's farmers adapt to climate change. World Bank Policy Research Working Paper 4758. Washington D.C. view at Google scholar / view at publisher

Watts, M. (1983). On the poverty of theory: natural hazards research in context. In: K. Hewitt (ed.) Interpretations of calamity from the viewpoint of human ecology, pp. 231-262. Boston, MA: Allen \& Unwin. view at Google scholar

World Bank (2006). Investment framework for clean energy and development. Washington, D.C.: The World Bank. view at Google scholar

World Bank (2010). The economics of adaptation to climate change. A Synthesis Report, Final Consultation draft, August 2010, The World Bank, Washington D.C. view at Google scholar 